\title{
GENERAL EDITOR'S PREFACE
}

This volume reflects the tremendous changes that have taken place in how both anthropologists and historians define the scope of ethnohistory since the Handbook of Middle American Indians was conceived in 1956. Although four volumes of the Handbook were devoted to ethnohistorical topics, not one of them contained substantive articles on the fate of Middle American Indian culture and society under Spanish rule. Unlike the other volumes of the Handbook, they were exclusively concerned with sources, not data. Furthermore, at that time anthropologists were making only limited use of historical documents to flesh out the archaeological record, and the only substantive ethnohistorical chapters in the Handbook could be found in the archaeological volumes. The emphasis on sources in the ethnohistorical volumes, on Late Preconquest ethnology in the archaeology volumes, and on recent ethnography in the ethnology volumes left a four-hundredyear gap in the Handbook's coverage of Middle American Indian culture history.
In the meantime, a growing interest in "documentary ethnology" among anthropologists and in "social history" among historians has shifted the emphasis of ethnohistorical research from the Late Postclassic to the Colonial period. The cumulative scholarship of the past two decades now makes it possible to identify and to explain regional differences in the Indian response to Spanish colonial policies, a point made by several contributors to this volume. Their finding is consistent with the variation in both Precolumbian and modern Indian cultures that was documented by the archaeology and ethnology volumes of the Handbook.

In supplementing the coverage of the Handbook, this volume bridges approximately three-quarters of the temporal gap that has existed for so long between prehistory and ethnography. It brings us to the end of the Colonial period, leaving for a later Supplement volume the impact of Independence on Middle American Indian culture and society.

V. R. B. 
THIS PAGE INTENTIONALLY LEFT BLANK 